\title{
EFFECT OF DIFFERENT ANGLE ON PULMONARY FUNCTION IN YOUNG HEALTHY FEMALES
}

\author{
Vidhi Shah ${ }^{* 1}$, Harita Vyas ${ }^{2}$.
}

${ }^{*}$ Postgraduate Student, Cardiopulmonary Department, S.B.B. College of Physiotherapy, V.S.Genaral Hospital, Ahmedabad, Gujarat, India.

${ }^{2}$ Lecturer, S.B.B. College of Physiotherapy, V.S.Genaral Hospital, Ahmedabad, Gujarat, India.

\section{ABSTRACT}

Background: Pulmonary function tests play an important role in the assessment, diagnosis, quantification of the ventilatory disorders intensity, and treatment course. Changes in posture can affect the resting length of respiratory muscles and the vestibular system contributes to altering respiratory muscle activity during movement and changes in posture. Aim of this study is to find different angle changes how effect on the pulmonary function.

Materials and Method: A cross sectional study was conducted on 30 young healthy females. Their Pulmonary function test was done with portable PFT machine in three various angles ( $45^{\circ}$ head down, $0{ }^{\circ}$ supine position, $45^{\circ}$ Oblique) by using tilt table.

Results: The result shows significant difference of FVC and FEV1 values in supine, oblique and head down positions [P value $=0.000]$. The values of FVC and FEV1 are highest in oblique position.

Conclusion: There was significant difference in effect of different angle on pulmonary function and it was highest in oblique $\left(45^{\circ}\right)$ position.

KEY WORDS: Pulmonary function, tilt table, different angle, ventilation.

Address for correspondence: Dr. Vidhi Shah. PT., Postgraduate Student, S.B.B. College of Physiotherapy, V.S.Genaral Hospital, Ahmedabad, Gujarat, India. E-M ail: vidhishah8393@gmail.com

\begin{tabular}{|c|c|c|}
\hline & \multicolumn{2}{|c|}{ Access this Article online } \\
\hline \multirow{2}{*}{$\begin{array}{l}\text { Quick Response code } \\
\text { Dol: } 10.16965 / \text { ijpr.2017.208 }\end{array}$} & \multicolumn{2}{|c|}{$\begin{array}{l}\text { International Journal of Physiotherapy and Research } \\
\text { ISSN } 2321-1822 \\
\text { www.ijmhr.org/ ijpr.html }\end{array}$} \\
\hline & $\begin{array}{l}\text { Received: 02-08-2017 } \\
\text { Peer Review: 02-08-2017 } \\
\text { Revised: None }\end{array}$ & $\begin{array}{l}\text { Accepted: 05-09-2017 } \\
\text { Published (O): 11-10-2017 } \\
\text { Published (P): 11-10-2017 }\end{array}$ \\
\hline
\end{tabular}

\section{INTRODUCTION}

Respiration means the occurrence of exhalation and inhalation in turns and the lung undertakes the role of exchange between air and blood [1]. This happens through respiratory muscles and their neurophysiological control. Change in body positioning and the consequent change of gravity effect, among other factors, cause change in respiratory function at different intensities [2]. Since respiration is a compound function requiring musculoskeletal and nervous system cooperation [3], changes in pulmonary function due to posture are markedly observable in patients with neurological disorders accompanying weakened respiratory muscles [4].

Pulmonary function tests play an important role in the assessment, diagnosis, quantification of the ventilatory disorders intensity, and treatment course [5]. The forced vital capacity (FVC) is a pulmonary function measure often used for this purpose and is defined as the maximum volume of air exhaled from after maximum inspiration $[5,6]$. Decreased FVC is a fairly obvious abnormality in patients with respiratory muscle weakness or changes in lung mechanics that overload these muscles $[6,7]$. Higher lung volumes have been linked with better expiratory muscle length-tension relationships [8,9] and improved expiratory pressures and flow rates [9].

Body position has been shown to affect lung volumes [10] and muscle biomechanics [11]. A large number of patients with neurological 
disorders who are mobility-impaired spend most of their time in bed and receive physical therapy in bed as well. Changes in cardiopulmonary function are important in finding out which angles are most convenient for in bed treatments and daily activities for such patients [12].

Thus, knowledge of the physiological effects of different body positions on pulmonary function is essential to guide the physical therapy procedures, including spirometry in clinical practice, so that its values are comparable between different periods and patients [13]. So the purpose of this study is to understand the influence of pulmonary functions on different angle by measuring breathing capacity in head down position $\left(45^{\circ}\right)$, supine position $\left(0^{\circ}\right)$ and oblique position $\left(45^{\circ}\right)$

\section{MATERIAL AND METHODOLOGY}

The research was conducted on 30 female students with the age of 20 to 25years. All subjects are voluntarily recruited after hearing explanations about the study and all subjects are without the history of pulmonary diseases or thoracic mutation / injury. We obtained an informed consent from subjects.

Procedure: The subject lies down on the tilting bed with leg straps/knee straps, but without chest straps in order to not disturb thoracic expansion and abdominal movements.

Pulmonary function testing was done in three different angles using the Portable PFT (Helios 702). The subjects were instructed about the procedure of the FVC (forced vital capacity) maneuver and were asked to perform it thrice. $\mathrm{A}$ brief rest of $30 \mathrm{~s}$ between trials was used to minimize the fatigue effect on the respiratory muscles [14]. The best value of the three was recorded. The lung function parameters studied were FVC (forced vital capacity), FEV1 (forced expiratory volume in 1 second).

The subject's breathing capacity was measured firstly in $45^{\circ}$ head down position, than in supine position and lastly measured after shifting to oblique position when the therapist switched the angle of the tilting bed to $45^{\circ}$.

Statistical analysis: Statistical analysis was done by using SPSS software version 16.0. Level of significance was kept at 5\%. Data did not follow normal distribution so non parametric test were used to analyse the data. Friedmen test was applied.

\section{RESULTS}

The result shows FVC,FEV1 values in supine, oblique and head down positions are $[1.6964 \pm 0.47801,1.6696 \pm 0.46623],[1.8128 \pm$ $0.51112,1.6916 \pm 0.53017]$ and $[1.5248 \pm 0.49698$, $1.5120 \pm 0.48345]$ respectively. Significant difference was found [ $p$ value $=0.000$ ]. The values of FVC and FEV1 are highest in oblique position.

Graph 1: FVC,FEV1 values in supine, oblique and head down positions.

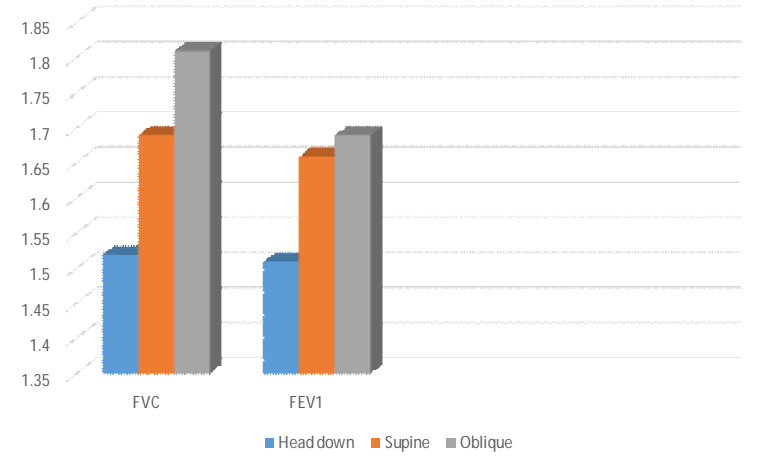

Table 1: Showing the mean FVC and FEV1 in three different angles.

\begin{tabular}{|c|c|c|c|c|}
\hline Parameter & $\begin{array}{c}\text { Head Down } \\
\left(\mathbf{4 5} 5^{\circ}\right)\end{array}$ & Supine & $\begin{array}{c}\text { Oblique } \\
\left(\mathbf{4 5} 5^{\circ}\right)\end{array}$ & P Value \\
\hline FVC (Liters) & $1.52 \pm 0.49$ & $1.69 \pm 0.47$ & $1.81 \pm 0.51$ & 0 \\
\hline FEV1 (Liters) & $1.51 \pm 0.53$ & $1.66 \pm 0.46$ & $1.69 \pm 0.48$ & 0 \\
\hline
\end{tabular}

\section{DISCUSSION}

Results of this study showed, average FVC, FEV1 values for Oblique $\left(45^{\circ}\right)$ is high and average value for Head down $\left(45^{\circ}\right)$ is smaller than for Supine $\left(0^{\circ}\right)$ and Oblique $\left(45^{\circ}\right)$.

Pryor et al. 1 stated that the $45^{\circ}$ oblique position is good for inhalation due to relaxed abdominal muscles [1].

In supine position, anatomical changes occur in the pharynx, such as the reduction of its diameter, which increases the upper airway resistance. The cephalic displacement of the diaphragm due to increased abdominal pressure, and the increased intra thoracic blood volume, are also factors that result in reduced lung volume at rest and justify an increase in airway resistance in this body position [15]. 
Standing has been shown to lead to the highest lung volumes [16]. At higher lung volumes there is greater elastic recoil of the lungs and chest wall [9]. and the expiratory muscles are at a more optimal part of the length-tension relationship curve and thus are capable of generating higher intra thoracic pressures $[8,9]$.

Barach and Beck (1954) found that emphysematous patients had relief of dyspnoea, decreased accessory muscle use and a mean decrease of $22 \%$ in ventilation requirements when placed in a 16 degree head down tilt. They attributed this to the diaphragm being displaced into the thoracic cavity by the abdominal contents [17].

As reported by Pankow et al FVC reduction in supine position $00 \%$ may be due to the reduction in alveolar area, and not only by the increased frequency of atelectasis [18].

Thus, knowledge of body positions that favor lung function can be used as a therapeutic measure, aiming at improving lung volume, oxygenation, and respiratory mechanics and minimizing disturbances produced by major surgical procedures, with reduced incidence of atelectasis and prevention of pulmonary complications [19-21]. Basic cardiopulmonary functions are important for normal persons as well as clinical patients with neurological damage to carry out their daily lives independently [22].

This study is deemed as sufficiently interconnected to treatment thus there is need for analytical research into diverse angles on patients. Also because this study set up safer treatment plans than actual clinical treatment, it could be used as reference.

\section{CONCLUSION}

There was significant difference in effect of different angle on pulmonary function and it was highest in oblique $\left(45^{\circ}\right)$ position.

\section{ABBREVIATIONS}

\author{
PFT- Pulmonary Function Test \\ FVC- Force Vital Capacity \\ FEV1- Force Expiratory Volume in 1 second
}

\section{Conflicts of interest: None}

\section{REFERENCES}

[1]. Pryor JA, Prasad SA. Physiotherapy for respiratory and cardiac problems, Singapore, Churchill Livingstone; 2011.

[2]. Gea J. La especie humana: un largo camino para el sistemarespiratorio. Arch Bronconeumol. 2008;44:263-70

[3]. Kapleri E, Vourazanis E, Strimpakos N. Neck pain causes respiratory dysfunction. Medical hypotheses. 2008; 70(5):1009-13.

[4]. Lee BK. The Effect Of The Forced Pulmonary Function of Young Female by Changes in Lung Function Related to Postures and by Transverse Abdominis Activation in Standing Position. J Korean Soc Phys Ther. 2012;7(3):267-74.

[5]. Sociedade Brasileira de Pneumologia e Tisologia. Diretrizespara testes de func,ão pulmonar. J Pneumol. 2002;28 Suppl.3:S1-238.

[6]. Gibson J, Whitelaw W, Siafakas N. Tests of overall respiratoryfunction. Am J Respir Crit Care Med. 2002;166:521-6.

[7]. Chevrolet JC, Deleamond P. Repeated vital capacity measure-ments as predictive parameters for mechanical ventilation needand weaning success in Guillain-Barré syndrome. Am Rev RespirDis. 1991;144:814-8.

[8]. M CCool FD and Leith DE. Pathophysiology of cough. Clinics in Chest Medicine 1987;8:189-195.

[9]. Leith DE. Cough. Physical Therapy 1968;48:439447.

[10]. Hough A. The effect of posture on lung function. Physiotherapy 1984;70:101-104.

[11]. Derenne JP, M acklem PT and Roussos CH. The respiratory muscles - mechanism, control and pathophysiology. American Review of Respiratory Disease 1978;118:119-205.

[12]. Kim IB, Kim EK, Kang JH. The influence of position change on autonomic nervous system function. J Korean Soc Phys Ther. 2014;9(1):63-8.

[13]. Wallace JL, George CM, Tolley EA, et al. Peak expiratory flow inbed. A comparison of 3 positions. Respir Care. 2013;58:494-7.

[14]. Hojat B, M ahdi E. Effect of different sitting posture on pulmonary function on students, Journal of physiology and pathophysiology, 2011;2(3):29-33.

[15]. Behrakis PK, Baydur A, Jaeger MJ, et al. Lung mechanics in sitting and horizontal body positions. Chest. 1998;83:643-6.

[16]. Wade OL and Gilson JC. The effect of posture on diaphragmatic movement and vital capacity in normal subjects with a note on spirometry as an aid in determining radiological chest volumes. Thorax 1951;6:103-126.

[17]. Barach AL and Beck GJ. Ventilatory effects of head down position in pulmonary emphysema. American Journal of Medicine 1954;16:55-60.

[18]. Pankow W, Podszus T, Gutheil T, et al. Expiratory flow limitation and intrinsic positive end-expiratory pressure in obesity. J Appl Physiol. 1998;85:1236-43. 
Vidhi Shah, Harita Vyas. EFFECT OF DIFFERENT ANGLE ON PULM ONARY FUNCTION IN YOUNG HEALTHY FEM ALES.

[19]. Valenza F, Vagginelli F, Tiby A, et al. Effects of the beach chair position, positive end-expiratory pressure, and pneumoperitoneum on respiratory function in morbidly obesepatients during anesthesia and paralysis. Anesthesiology.2010;107:725-32.

[20]. Dean E. Effect of body position on pulmonary function. Phys Ther. 1985;65:613-8.

[21]. Franc, a EET, Ferrari F, FernandesP, et al. Fisioterapia empacientes críticos adultos: recomendac,ões do Departamento deFisioterapia da Associac,ão de M edicina Intensiva Brasileira. RevBras Ter Intensiv. 2012;24:6-22.
[22]. Kim SY, Kim NS, Jung JH, JO MR. Effect of Forward Head Posture on Respiratory Function in Young Adults. J Korean Soc Phys Ther. 2013;25(5):311-5.

\footnotetext{
How to cite this article:

Vidhi Shah, Harita Vyas. EFFECT OF DIFFERENT ANGLE ON PULM ONARY FUNCTION IN YOUNG HEALTHY FEMALES. Int J Physiother Res 2017;5(5):2356-2359. DOI: 10.16965/ijpr.2017.208
} 